\title{
Overlooking British Experiences: a reply to Evershed
}

\author{
Dr Matthew Johnson \\ m.johnson@lancaster.ac.uk
}

This is an Author's Original Manuscript (AOM) of an article published by Bristol University Press in Global Discourse on 22 September 2019, available online: http://dx.doi.org/ $10.1332 / 204378919 X 15646709278039$

\section{Biography}

Matthew Johnson is Lecturer in Politics in the Department of Politics, Philosophy and Religion at Lancaster University, Bailrigg, Lancaster, LA1 4YL, United Kingdom; email: m.johnson@lancs.ac.uk. His research focuses on the relationship between culture, public policy and wellbeing, examining such topics as informal welfare systems, indigenous politics and genital cutting. He is founding editor of Global Discourse (tandfonline.com/loi/rgld20) and author of Evaluating Culture (London: Palgrave MacMillan, 2013).

\begin{abstract}
Jonathan Evershed (2019) presents a compelling account of the clear dangers that lie in forms of state-led remembrance. The danger is, of course, that, in commemorating, actual experience is lost. While I do not wish to challenge any of the core claims in the piece, I do think that there is one element that requires greater examination: Evershed's claim that contemporary Irish conceptions of WWI as 'A war that stopped a war' 'contributes to a (post)colonial and militaristic nostalgia in British political culture'. While the dangers of that for Northern Ireland are clear, perhaps the greatest risks lie in England, since any such benign account of the conflict serves radically to distort the experience of those soldiers commonly regarded as identifying as British and painted as being motivated by patriotism. Drawing on experience from Tyneside, I argue that, in considering the nature of that conflict, we must remember the many diverse, and often banal, reasons for working class engagement in conflict.
\end{abstract}

Keywords: Remembrance; Commemoration; WWI; Britain; Ireland; Unionism; Nationalism

In contrast to the community-led forms of remembrance examined by Hinson (2019) and Oppenheimer (2019) in this issue, Jonathan Evershed (2019) presents a compelling account of the clear dangers that lie in forms of state-led remembrance. The danger is, of course, that, in states' forging forms of official commemoration, actual experience of participants is lost. While I do not wish to challenge any of the core claims in the piece, I do think that there is one element that requires greater examination: Evershed's claim that contemporary Irish conceptions of WWI as 'A war that stopped a war' 'contributes to a (post)colonial and militaristic nostalgia in British political culture'. While the dangers of that for Northern Ireland are clear, perhaps the greatest risks lie in England, since some accounts of the conflict serve radically to distort the experience of British soldiers and retrospectively painted as being motivated solely by much more modern forms of patriotism.

The irony of Irish narratives is that they support, in certain respects, forms of official British narration that present soldiers' choices in ways that might confound the soldiers themselves. My grandfather fought in WWII and his father in WWI. I recall, prior to my grandfather's death, asking him whether his father, my great-grandfather, would have been prepared to die for his country. He was incredulous. "Why would he be prepared to die for his country?' For my grandfather, the thought that soldiers were collectively motivated by limitless patriotic pride was nonsense. For a start, those soldiers often had entirely different conceptions 
of nationhood and country to those we have today. For my great-grandfather, who came from a small mining community in County Durham, and whose greatest migration was the eight or so miles to the north bank of the Tyne, the notion of his being British in any modern sense was fanciful. This was a man who was grounded in his locality, whose identity was either villagelike or, by virtue of his union work, informed by the Labour movement. Often, my grandfather would describe his experiences in WWII in the most exotic terms, not primarily with regard to his work in Egypt, but in his engagement with other men from the British Isles, few of whom he could understand with great ease. If this were his experience, and if he had been exposed to mass media through moving pictures, imagine the utter discord faced by men from the provinces in WWI. More often than not, they would be in locally raised regiments, but they would be fighting alongside people from radically different backgrounds and regions. The notion that all of these men were motivated by concern for Britishness is problematic.

The second, potentially pernicious, narrative that the Irish account endorses is a retrospective mis-application of a justification for WWII (upholding liberty) to WWI (see, for example, Shipman 2014). Not only was liberty a wholly abstract concept for the vast majority of ordinary soldiers, it is deeply concerning that narratives appear to apply fascist tendencies to Germans of generations prior to WWII. For soldiers like my great-grandfather, the greatest source of oppression came from church and landed wealth in his pit village and then capital in the city. In this post-feudal context, while many men did not have a clear sense of nationhood, they did have a clear sense of military obligation. This was not necessarily civic duty, but a post-feudal obligation to provide military service, often at the pain of destitution or death. For my grandfather, avoidance of service through self-inflicted wound or avoidance was 'stupid'. Fundamentally, there was a basic acceptance of risk in people's lives that is now forgotten. People faced daily risk of serious injury and death at work, just as women did in childbirth. Death was public and common. While the risk of death in WWI was initially underestimated, the risk of death through destitution or the criminal justice system for avoidance of service did lie in people's minds. My grandfather long lamented dispensing with an official document that stated the penalty for not returning to duty following Leave was death. Concern about cowardice was not simply grounded in people's military service, it also spoke to the reliability of individuals in a social setting. When people have to rely on one another for their very lives, such as in mining, the notion of cowardice has an everyday relevance to people's considerations. Many men who fought in WWI were navigated risk with bravery, but also resignation.

In this sense, service could be banal and could be mundane. Such service could bear few of the hallmarks of narratives of remembrance we see on either side of the Irish Sea. Indeed, for men like my great-grandfather, memories passed down generations often bear the hallmarks of episodic comedic cunning and failure: my great-grandfather as the man brave enough to volunteer to hunt down a sniper in no-man's land, but daft enough to demonstrate such insubordination as to deprive himself of a medal; the man clever enough to stow himself away back to Walker for unauthorised leave, but daft enough to go back at the end of troop rotations, just in time for another big push; the man shrewd enough to steal a bell from a church tower, but daft enough to try to hawk it in a town deserted by refugees. The satire of Bobby Thomson speaks to the inevitable and deeply comedic struggle and failure of working-class people to transform their circumstances. For people like my great-grandfather, the narratives imposed upon their lives sometimes confirm this: in death, as in life, they are beholden to the fantasies dreamt by those that inherited the profits of their labour.

At a time in which the potential for radical, transformative politics lies most clearly on the East, rather than West, shores of the Irish Sea, it is essential that those on the left retain scepticism of state-crafted narratives. In the context of Evershed's compelling work, it is also essential that the narratives that present Britain and Ireland as cultural or political binaries is 
challenged. My great-grandfather came from a Catholic community, married an Anglo-Irish dancing champion; his son married my grandmother, whose family were Northern Irish Catholics. In a sense, they only became substantively, self-consciously British through the work of the 1945 Labour government in creating national institutions that advanced people's interests.

Noting this is not to undermine the work of soldiers or to detract from our memory of them and their service. These were ordinary people who often did extraordinary things in appalling circumstances. It is, though, to emphasise the importance of scepticism in official narratives and, indeed, those counter-narratives that present groups of people as standing in immutable ethno-cultural opposition to one another. Whatever their historical participation in conflict, for the working-class people of Northern Ireland, it is not at all clear that a progressive future lies in unification with the Republic.

\section{References}

Evershed, J. (2019) 'A war that stopped a war? The necropolitics of (Northern) Ireland's First World War Centenary', Global Discourse, 9:3.

Hinson, E. (2019) “"Our Journey, Our Narrative": Narratives of Para(militarism) and Conflict Transformation in the ACT Exhibition', Global Discourse, 9:3.

Oppenheimer, R. (2019) 'Analyzing Contested Pasts: Reply to Hinson', Global Discourse, 9:3.

Shipman, T. (2014) 'Michael Gove blasts 'Blackadder myths' about the First World War spread by television sit-coms and left-wing academics', Daily Mail, $3^{\text {rd }}$ January, <https://www.dailymail.co.uk/news/article-2532923/Michael-Gove-blastsBlackadder-myths-First-World-War-spread-television-sit-coms-left-wingacademics.html> [Accessed 04 July 2019]. 